\title{
OS CAMINHOS “ERRANTES” DE ÉDIPO. A SACRALIZAÇÃO DO SABER POSITIVO. O MISTÉRIO PROFANO
}

\author{
KATHRIN HOLZERMAYR ROSENFIELD* \\ Instituto de Filosofia e Ciências Humanas \\ Universidade Federal do Rio Grande do Sul
}

\begin{abstract}
RESUMO: Este artigo ilumina o novo lugar que a poesia de Sófocles reserva ao saber e à figura do adivinho. Realça os elementos que diminuem as conotações religiosas da intervenção de Tirésias em Édipo Rei. Mostra as técnicas com as quais o poeta sugere que o saber dos oráculos e o destino surgem de um limiar do "adivinhar" profano que envolve, como um halo, a produção do conhecimento positivo e as atitudes práticas da experiência humana.
\end{abstract}

PALAVRAS-CHAVE: Édipo Rei; saber mântico; conhecimento humano.

Nenhum herói trágico é tão próximo das nossas preocupações modernas quanto Édipo, que Freud transformou no paradigma do saber psicanalítico - para o desgosto de muitos helenistas. Embora os comentários sobre a peça de Sófocles sejam muito sumários, é claro o que interessa Freud neste herói, como em outras figuras literárias - de Hamlet aos personagens de E.T.A. Hoffmann e Schnitzler. No centro de suas análises estão os sintomas multifacetados do conflito "edipiano" - a estranha associação de rapidez e lentidão do pensamento, as oscilações bruscas entre ternura e ira, a solenidade ritual que se dissolve em acessos de ira. Em todos estes fenômenos, Freud registrou os processos psíquicos que minam a consciência e a identidade racional, tornando poroso o conhecimento que temos de nós mesmos e do mundo (FREUD, 1968, v. II/III, p. 267-71; v. XI, p. 342-4; v. XIV, p. 412). Apesar das geniais intuições freudianas, suas misturas de casos clínicos com análises literárias não fizeram sucesso entre os estudiosos da Antigüidade clássica. As abordagens históricas e estruturais evidenciaram a trama de representações específicas que ordena o imaginário do saber, do poder e do desejo e elaboraram o sistema de oposições do pensamento grego sem projeções modernas (MARSHALL, 2000 , c. I). 
Embora longe das analogias freudianas, Charles Segal reconhece, entretanto, uma analogia entre Hamlet e Édipo. Ela está na potência dramática destas peças que se tornaram o paradigma "da suspensão da existência humana entre capacidades extremas e contraditórias [...] onde a ordem racional e compreensível dissolve-se em mistérios" (SEGAL, 1999, p. 43). Da mesma forma, Jean-Pierre Vernant ressalta que "no novo quadro do jogo trágico... o herói deixou de ser um modelo; tornou-se, para si mesmo e para os outros, um problema" (VERNANT, 1989, p. 14). Onde Vernant analisa as expressões históricas da ambigüidade e de reviravolta trágicas, Segal sublinha a tensão entre a limitação humana e as possibilidades incomensuráveis dos deuses. Com efeito, no início de Édipo Rei, as súplicas dos cidadãos criam uma "representação vívida e visual da qualidade sacral da realeza de Édipo, de sua posição exposta entre forças humanas e sobre-humanas". "Assumindo a função perigosa de interceder entre o sagrado e o profano,... ele é, como diz o velho sacerdote 'o primeiro dos homens... nos encontros com os deuses' (vv. 33-4). A ironia específica do fato que Édipo sofre os males do seu povo mais do que ninguém e sente o luto da cidade mais do que se lamentasse a própria vida (vv. 59-64, 93-94) é uma trágica intensificação da posição exposta do rei entre a ordem social e o reino numinoso, entre as instituições seguras da civilização e o desconhecido" (SEGALL, 1999, p. 44-5).

Literal e figurativamente, Édipo é o emblema vivo do ser-exposto entre a pureza da palavra divina e os rumores inconsistentes que agitam a sociedade humana, entre, de um lado, a verdade celestial, de outro, os fantasmas, as ânsias e suspeitas humanos. O velho sacerdote realça, no prólogo, esta posição destacada de Édipo: "Liberaste Tebas do tributo da cantora atroz (dura) / sabendo nada sobre nós e sem ter sido instruído, / mas pelo dom dos deuses (prosdeke theou) (BL 35-6, H 36- $7^{1}$ ).

O herói parece lembrar-se do elogio homenageando esta excelência quando se gaba, diante de Tirésias, de ter conquistado o bem da cidade sem o concurso da vidência: "Eu, o não instruido (meden eidos) Édipo, fiz calar (a cantora), atingindo-a com o entendimento (gnomé), não ensinado (oud'... mathô) pelos pássaros" (H 401, BL 403).

Do elogio do sacerdote ao auto-elogio do herói, ocorre um leve deslocamento do foco. O primeiro fala, de modo vago, de um dom ou concurso divino, ao passo que Édipo orgulha-se de suas próprias faculdades independentes da técnica sacerdotal da divinação. Para além das análises bem conhecidas que evidenciaram Édipo como o mediador entre o sagrado e o profano, entre as instituições sociais e 
as forças numinosas, entre o conhecimento racional e o inominável ${ }^{2}$, mostraremos como esta tragédia conquista realmente uma zona intermediária e plenamente humana, na qual é impossível separar a vidência sagrada do conhecimento profano. Isto não significa, entretanto, qualquer irreverência ou desrespeito religioso. $\mathrm{O}$ Édipo de Sófocles aparece, antes, como a figura que sacraliza as aptidões "profanas", dando uma aura grandiosa às formas especificamente humanas de conhecer e agir eticamente. Como Prometeu de Ésquilo, porém de modo mais realista ou mais concreto, a figura de Sófocles faz aparecer o que há de "divino" na trama labiríntica das diversas aptidões humanas, embora estas sejam lentas e falhas: no esforço sincero, no rigor do raciocínio, na precisão da observação, no registro das sensações opacas do corpo, na fidelidade aos sentimentos anódinos e às intuições obscuras $^{3}$.

Édipo e Tirésias são detentores de duas formas de saber distintos. Édipo sente-se como o guardião de um saber que tem grande relevância institucional, ele defende os saberes jurídicos, políticos e científicos que transitam, como competência ou propaganda, na polis clássica. Mas a revira-volta trágica faz entrever que esta competência segura é, ao mesmo tempo, um engodo. Se o rei de Tebas parece brilhar no domínio da inteligência humana, o profeta na sabedoria divina e inspirada, a lógica da poesia trágica torce e inverte a visão compartilhada pelos próprios personagens da peça e pelos contemporâneos atenienses de Sófocles. Creonte, o Coro e Édipo, pelo menos no início do diálogo com Tirésias, parecem confiar na sabedoria do vate. Mas a elaboração poética de Sófocles vai muito além destas oposições estáticas, subvertendo as expectativas convencionais com ardis da gramática e do léxico.

Se os personagens do drama confiam na verdade divina, essa confiança é frágil por parte de Édipo e logo evidenciará barreiras que farão saltar as delimitações nítidas entre o sagrado e o profano, acirrando o que há de dúbio no saber mântico e o que há de admirável - e misterioso ou inominável - nos modos de saber dos homens. Jean-Pierre Vernant já assinalou que há um "discurso secreto que se institui, sem que ele o saiba, na fala de Édipo, [e que o herói] não o entende. E nenhuma testemunha do drama no palco, fora Tirésias, tampouco é capaz de percebe-lo" (VERNANT, 1972, v. I, p. 105). Em geral, esta discrepância é atribuída ao hiato incomensurável que separa - na maioria das tragédias, inclusive do próprio Sófocles - a palavra divina dos discursos humanos. No entanto, em Édipo Rei, Sófocles parece ter-se empenhado em eliminar todas as conotações mágicas e sobre-humanas do saber mântico, mostrando, na figura de Édipo e na de Tirésias, 
uma mesma inteligência intuitiva. Tanto o herói como o vate baseiam-se tão somente na observação rigorosa dos indícios empíricos para rastrear as verdades relevantes para o convívio humano.

\section{Deslocamentos entre o saber mântico e o conhecimento humano}

Édipo atribui a Tirésias um saber sagrado que falhou, salientando cruamente que as técnicas sacerdotais da vidência foram impotentes e deixaram Tebas à mercê do flagelo da Esfinge. Esta evidência, cruamente proclamada, estabelece, por um momento, uma relação de rivalidade: Édipo coloca Tirésias no mesmo plano e compete com o vate na esfera do bem público ${ }^{4}$. Ao mesmo tempo, ele apresenta Tirésias como um cúmplice de Creonte, mero instrumento na rivalidade pelo poder. Ele expõe a pessoa do vate - não sua palavra - ao julgamento da cidade e sugere que as falas do vate visariam interesses inconciliáveis com suas funções sacerdotais. Sua atitude despoja o vidente das honras da sua arte. Tekhne e mantike são os termos específicos para a sabedoria reservada a certos especialistas reunidos em famílias sacerdotais, cujo dom divino estabelece a comunicação com um saber sobre-humano. À primeira vista, é a hybris de Édipo que parece desmerecer a honra do vate. No entanto, Sófocles complica essa aparência através do uso estratégico do vocabulário que dá razão às suspeitas do herói de que existe um plano onde Tirésias e ele mesmo estão numa competição meramente humana.

A sede corporal do saber profético são os phrenes, o diafragma, onde ocorre o domínio do sopro das práticas meditativas. Ora, o pensar verdadeiro e reto dos homens, phronein, igualmente surge deste órgão e Sófocles constrói, em Édipo Rei, uma trajetória sui generis que complica e borra as diferenças nítidas entre as formas humanas e divinas de saber. Francisco Marshall fornece um excelente resumo da abrangência dos sentimentos, representações e pensamentos que surgem deste âmago das atividades espirituais humanas. Lembra que o "reto pensar", orthos phronein, ponto de referência freqüente dos personagens desta tragédia, expressa não tanto o pensar racional e cerebral do noûs, mas a atividade das entranhas do ser intelectivo. Ele emerge do órgão que deseja, ingere e absorve os alimentos e as bebidas e que transfere para os demais órgãos anímicos (thymos e noûs) os humores e estados sensíveis aí produzidos (temor, júbilo, incômodo, amor, etc.). Magnien e Marshall assinalam também que um enfraquecimento excessivo desta faculdade (phrenes ou phrén) induz estados de imbecilidade e de estupor, aproximando o ser humano de uma insensibilidade equivalente à morte (MARSHALL, 2000, p. 153; MAGNIEN, 1927, p. 117-41). 
Ora, é significativo, neste contexto, que as acusações de Édipo contra Tirésias visam precisamente a aparente indolência do silêncio do vate. Sua indiferença insensível é censurada com a metáfora convencional da frieza da rocha que designa a inércia desumana do mineral. Quando ele confronta o saber estéril e inoperante do vidente com o seu próprio, ele não fala apenas da discrepância dos resultados. Desde o início, Édipo se orgulha de seu zelo e o sofrimento, do árduo caminho labiríntico (phrontidos planois, v 67) que ele percorreu ao conquistar e salvar a cidade. É esta sabedoria viva, sofrida, conquistada ao longo de um tempo considerável, que ele diferencia do saber de Tirésias que ora se recusa friamente de falar, ora profere fórmulas enigmáticas com uma atitude de indiferença e despeito, lançando não só Édipo, mas também o Coro na estupefação.

Propomos, portanto, considerar com mais vagar o uso que Sófocles faz do léxico derivado do verbo phronein. Ao que parece, o poeta valoriza e dramatiza o que esta atividade representa para o entendimento hipocrático. No contexto científico do século quinto, não se trata de uma função meramente intelectual, mas de um exercício efetivo das faculdades do espírito, oposto aos modos patológicos de pensar (paraphroneîn) ou delirantes (mainesthai), como também à arrogância (authadian 549) ${ }^{5}$. O fato que Édipo fala com Tirésias no registro da competição, medindo-se de homem para homem com o vate para saber quem melhor serviu e serve a cidade, não é, portanto, apenas uma desmedida e uma cegueira do herói sobretudo quando observamos que o próprio vidente dialoga com Édipo no registro do saber oriundo da experiência no tempo físico dos homens. Vejamos, neste sentido, a especificidade das falas de Tirésias em Édipo Rei, confrontando-as com os vaticínios em outras tragédias, em particular em Antígona.

Em Antígona, por exemplo, a palavra pura do vaticínio irrompera realmente na forma de visões momentâneas. Elas caem como raios e despertam "algo" que inexistia na memória anteriormente a esta inspiração, cuja luz ofusca doravante o que parecia verossímil na ordem dos pensamentos cotidianos e razoável na ordem das deduções e dos cálculos empíricos. É neste ponto que reside a diferença de Édipo Rei: neste peça, nunca veremos representado um transe inspirado, nem a irrupção pura de um oráculo. A verdade divina aparece tão somente na forma de signos acessíveis ao entendimento humano - embora este acesso dependa do tempo - sofrido e lento - da experiência humana.

Assim, aparece uma zona opaca que vincula e imbrica os termos da oposição: sob este ângulo, aparece a afinidade do pendor racional de Édipo (cujo parentesco com o iluminismo do século $\mathrm{V}$ já foi assinalado) com a inspiração aparentemente irracional ou sobrenatural-dos profetas. Por exemplo, chama atenção que 
Tirésias entra em cena sem reivindicar qualquer valor profético para suas declarações. Na primeira metade de seu diálogo com Édipo ele nunca menciona que suas palavras foram inspiradas, nem oriundas de um ritual profético. Em nenhum momento ele fala de uma das técnicas do vaticínio que Sófocles descreve exaustivamente em Antígona. Pelo contrário, o Tirésias de Édipo Rei refere-se sempre a uma forma de conhecimento ou de reconhecimento que caracteriza o racionalismo contemporâneo e posterior aos trágicos.

O que mais distingue Édipo Rei de outras tragédias é o modo humano da apresentação, o ponto de vista rigorosamente finito que implica todos como membros solidários de um mesmo universo limitado e propenso ao sofrimento. $\mathrm{O}$ aspecto que levantamos não contesta as análises que salientam o conflito entre o saber racional e o inspirado. A primeira tensão dramática repousa, sem dúvida, sobre o conflito de competências cognitivas, opondo o saber empírico dos homens ao saber numinoso, reservado aos deuses e profetas. No entanto, o trabalho poético de Sófocles mostrará que a competência de Édipo não surge de uma razão diretamente disponível. Embora o herói tenha resolvido o enigma da Esfinge, ao que parece com espantosa rapidez, sua gnomé repousa - muito mais do que ele mesmo suspeita - sobre uma longa familiaridade com o sofrimento. Sua trajetória é, essencialmente, um rastreamento do sofrimento esquecido e ocultado que o vitimou. Não é, portanto, mera metáfora quando ele diz, que seus pensamentos trilharam “caminhos errantes" à procura para uma saída do flagelo da peste. Já no passado ele precisou enveredar pelos caminhos imprevisíveis de um exílio auto-imposto, para finalmente cruzar caminho com a esfinge. A enigmática peste abre nova trajetória na qual o herói se perde no labirinto de pensamentos, raciocínios, sensações e suspeitas que ele não consegue situar na ordem do tempo e do espaço.

As sutis articulações do texto mostram, além da agilidade de deduzir e concluir, uma fina percepção - quase um faro - por certos signos sublimiares (demora, hesitação, lentidão, palavras cautelosas, formulações eufemísticas, etc.) que sobre-determinam o sentido do que é dito explicitamente. Édipo desvendará uma verdade que todos procuram ocultar. Ele parece sentir que o otimismo de Creonte ao retornar de Delfos é postiço, que o ânimo otimista encobre uma inquietação profunda. Ele registra as hesitações do cunhado ao falar em público e as evasivas respostas quando este procura explicar a negligência na apuração do assassinato de Laio. É preciso admitir que estes detalhes não são vãos fantasmas alimentando suspeitas infundadas do herói. Neles aparece um resíduo de esquecimentos culpados que é essencial para a descoberta de "toda a verdade" de Tebas. E um resíduo análogo reaparecera novamente no modo como Tirésias ora cala, ora profere as 
acusações contra Édipo. O que resta inexplicável no prolongado silêncio do vate e nos rodeios que antecedem suas revelações converge com a estranha discrição e as omissões dos outros personagens que o herói registra, perplexo, como elementos de um enigma muito mais amplo que ultrapassa a procura do assassino de Laio.

Neste sentido, é necessário analisar, para além do conflito que opõe a gnomé e a mantiké, um conflito no interior da gnomé. Esta opera, com efeito, com diferentes formas de saber, com sensações, sentimentos e pensamentos que ocorrem simultaneamente na experiência humana e combinam-se à revelia da consciência. O homem que deseja dominar, compreender e dirigir a vida pública ativamente, precisa apropriar-se da trama de seus sofrimentos, percorrer o labirinto de suas experiências corporais e intelectuais, para avaliar a trama de seus feitos dispersos no espaço e no tempo. Este saber de corpo e mente que surge das entranhas age à revelia da consciência, revelando-se somente no traçado daquilo que foi feito, mas que o tempo segmenta, apaga e entrega ao esquecimento ${ }^{6}$. Ninguém - nem mesmo Tirésias - é isento, todos participam como agentes e pacientes da ação. $\mathrm{O}$ verbo phronein, que distingue a inteligência e a ponderação humanas, é a palavra com a qual Tirésias abre seu diálogo com Édipo (H 320-1). No verso seguinte, a menção lutuosa do ritmo - mais que humano - que alterna saber e esquecer coloca Tirésias ainda mais no âmbito do saber falho e errante da experiência humana: "Como é terrível ver/entender (phronein, pensar, saber) onde isto não oferece saída a quem entendeu/viu. Aquilo que eu bem / sabia, eu o esqueci (diôles) [ao vir aqui]".

Tirésias sublinha expressamente que ele está - exatamente como o herói - perdido no labirinto de saberes inconclusivos, de esquecimentos e lacunas que assemelham a vida humana muitas vezes a um beco sem saída. É natural e, provavelmente também intencional por parte de Tirésias, que esta formulação provoque os reflexos competitivos do herói, cuja existência, poder e reputação estão baseados na agilidade do olhar, do raciocínio e no poder sintético de suas conclusões.

Não é apenas a desmedida do herói que provoca uma insensata competição entre a investigação racional e a forma reservada e misteriosa do saber proféticos. Embora seja verdade que seus sucessos com o enigma da Esfinge levem Édipo à soberba de ironizar as capacidades e intenções do vate, há outros fatores que complicam a situação e que fazem com que Tirésias e Édipo apareçam como competidores no mesmo domínio. Ao ser denunciado como fonte da polução que originou a peste, Édipo denuncia, por sua vez, a inoperância do saber de Tirésias. Ele desqualifica menos a "arte", tekhne, da vidência, do que os abusos e simulacros de 
oráculos, ditados por interesses humanos vis. Desde sua chegada em Tebas, o herói testemunhou a estranha omissão do vidente que se manteve alheio às aflições da cidade - ao ponto que, mais tarde, no diálogo com Creonte, Édipo pergunta se Tirésias já ocupava seu posto na época da morte de Laio. A distância lhe parece um indício de omissão culposa e levanta a suspeita de que Tirésias possa agir como instrumento da sede de poder de Creonte. $\mathrm{O}$ estranho comportamento inicial de Tirésias, seus subterfúgios com pensamentos e esquecimentos fornecem os motivos pelos quais Édipo põe em dúvida todo o saber "forte e verdadeiro" que reivindica Tirésias: "T: [...] Nutro o verdadeiro [talethes] como forte [apóio]. É: Ensinado por quem? Pois ele não vem da tua arte mântica (tekhnés)" (BL 356-7, H 360-1).

Alethés significa o verdadeiro, o franco, o que se realiza efetivamente, o que é real em oposição aos engodos ilusórios. No entanto, existem ecos e evocações etimológicos nesta fórmula que se conectam com os núcleos dramáticos da trajetória de Édipo, com a necessidade de desvendar o oculto e de lembrar o esquecido. Pois alethéia e alethés falam concretamente do não-esquecido ${ }^{7}$. A etimologia cria um vínculo íntimo entre o verdadeiro e aquilo que é mantido vivo na memória. Devido a esse elo, não existe, na Grécia antiga, uma "oposição nem contradição entre o verdadeiro e o falso - escreve Marcel Détienne em Os Mestres da Verdade (DÉTIENNE, 1979, p. X) -, mas entre os dois pólos [a verdade (Aletheia) e o esquecimento (Lethé)] cria-se uma zona intermediária na qual Aletheia desliza em direção a Léthé e reciprocamente. A negatividade não é, portanto, isolada, colocada à distância do Ser; ela rodeia a verdade [como o cós rodeia uma saia], ela é sua sombra inseparável.” A palavra grega que usa Tirésias diz literalmente que o verdadeiro é o não-esquecido. De fato, na tragédia Édipo Rei, a verdade não surge repentinamente com a revelação divina ou mágica, mas tão somente na forma da recuperação de elementos que caíram no esquecimento. Édipo o suspeita desde o início quando insiste sobre a importância de pequenos detalhes esquecidos ou negligenciados, e uma análise dos lapsos, das elisões e coincidências mostrará o quanto ele tem razão - inclusive no que diz respeito ao saber de Tirésias.

\section{As três formas de saber - ou: uma nova forma de saber que reúne conhecimento humano e oráculo divino}

Seguindo a sugestão de Détienne, poder-se-ia dizer que Édipo Rei, mais que qualquer outra tragédia, corta um novo limiar entre o imaginário arcaico (que supõe um saber outro, inacessível aos comuns dos mortais) e a consciência iluminista clássica. Nesse limiar, o saber divino e o humano começam a confundir-se ou a 
unir-se em formas cada vez mais ambíguas de intuição. A gramática trágica, o uso do vocabulário, a exploração das ambigüidades da vida e da linguagem tecem numa mesma trama a experiência vivida e os relatos que dão conta desta experiência. Assim, confundem-se as verdades da divinação com os conhecimentos do homem racional e com as intuições mais obscuras da pessoa - aquelas aptidões (sub)humanas do homem-criatura que fareja o imponderável das palavras nas tênues modulações da voz, do olhar e do gesto. Cria-se, assim, uma zona de indistinção entre os costumes milenares da palavra eficaz, os novos métodos de investigação positiva e as exigências de uma sensibilidade viva, sofrida-e-prazerosa, que não se deixa reduzir nem à primeira, nem à segunda forma de saber. Nessa zona altamente ambígua Sófocles constrói um processo que ocorre (ou poderia ocorrer) simultaneamente em três níveis. Não se trata mais da clivagem abstrata que isola a verdade transcendente (o saber profético) da aparência enganosa dos erros humanos. O que ocorre, é uma dramatização de duas formas de saber (o profético e o positivo) que se conjugam graças a uma terceira forma de vivência-inteligente ou de inteligência-viva-e-sensível ${ }^{8}$. Desde o início da peça, as ações de Édipo são acompanhadas de uma gama de manifestações emocionais oscilando entre a impaciência e o temor, entre inquietudes e vergonhas, suspeitas e pavores obscuros. $\mathrm{O}$ herói erra num labirinto de sensações e sentimentos que minam seu otimismo ao mesmo tempo em que o suscitam. Aceitar a errância neste labirinto permite aceder a uma verdade que escapava ao entendimento quando apresentada na forma enigmática dos anúncios de Tirésias.

Pois o que está em jogo não é apenas a duplicidade do indivíduo Édipo (estranho e parente), mas o enigma de seu triplo ser - estranho, parente e reiconquistador (tirano) que reergueu Tebas. Não são de pouca monta os elogios do sacerdote e do Coro agradecidos pela restituição das trocas regulares (Édipo liberou Tebas do tributo da cantora, isto é, da devoração dos jovens que congela a vida na esterilidade). Embora Sófocles mantenha sob silêncio o caráter específico do tributo exigido pela Esfinge, o primeiro, como também o novo flagelo da peste, dizem respeito ao problema da fertilidade e da procriação. $O$ retorno do filho exposto de Laio reverte, ao mesmo tempo, a esterilidade do soberano e da cidade. Com efeito, Édipo é o próximo parente que os pais afastaram para preservar o trono de Laio. Nos mitos antigos, as crianças maléficas que sobrevivem à exposição (ou a outras ordalias) transformam-se em seres benéficos - modelo imaginário que está ainda bem presente em Édipo. O herói que se chama, orgulhoso, filho da Sorte, transforma a antiga imagem da vida perene, numa nova figura de uma vitalidade física e intelectual, corporal e espiritual. É este vigor que reúne a força 
natural aos artifícios da civilização que ultrapassa todas as categorias, erguendo-se como um enigma diante do próprio herói, mas acuando também a sabedoria de Tirésias. Não é de se admirar que, nestas circunstâncias, o vidente tenha que abdicar, deixando ao tempo - isto é, à sofrida experiência humana - a tarefa de revelar os rastros sinuosos da verdade, isto é, o traçado preciso da história: da totalidade das etapas esquecidas que levam da geração de Laio à de Édipo. Tratase de ver, portanto, que o foco da tragédia não é a revelação da identidade de Édipo, mas a dramatização dos caminhos sinuosos e dolorosos que o homem tem que percorrer para chegar a fazer-se uma imagem de sua existência (HÖLDERLIN, 2001, p. 163). Esta representação verdadeira do sentido de nosso ser depende do rastreamento minucioso dos sentimentos miúdos, do medo e da alegria, do terror e do júbilo, das suspeitas e inquietudes que acompanham nossas ações e palavras.

\section{Suspeitas - erradas ou errantes??}

Vejamos como as três formas de saber se imbricam nas suspeitas e nas acusações que Édipo lança contra Tirésias e seu cunhado. A impossibilidade de reconstituir os fatos do passado devido aos esquecimentos e às omissões do passado desloca as esperanças do Coro, e do próprio Édipo, para as revelações de Tirésias. Assim, sua entrada em cena suscita grandes expectativas. Mas o silêncio do vate adiciona incertezas às suspeitas que Édipo concebeu no diálogo com Creonte. Conseqüentemente, a consulta desloca-se entre-cálculos e suposições, descarrilando-finalmente nos insultos que levam Tirésias às-suas enigmáticas acusações que Édipo compreende como manipulações de uma intriga palaciana. As insatisfatórias explicações sobre a morte não purificada de Laio, as hesitações de Creonte e o silêncio de Tirésias aparecem como os sinais inequívocos de um complô urdido pelo cunhado e o vate. O "zelo com as evidências" (MARSHALL, 2000, p. 197) faz com que Édipo se sinta ameaçado no seu poder. Suas intuições lhe dizem que os ardis de Tirésias não somente custaram a vida ao antigo rei, eles continuam ameaçando, no presente, o atual detentor do trono tebano.

O herói erra, evidentemente, quanto às intenções que o vate e Creonte cultivam no presente. No entanto, este "erro" é apenas um périplo no traçado errante que levará Édipo a conhecer - além das suas próprias ações horrendas os gestos inomináveis dos seus próximos que puseram em movimento sua trágica errância. Encaixadas numa outra seqüência temporal, as suspeitas do herói não são carentes de fundamento, de forma que poderíamos considera-las mais como 
"errantes" (ainda não encaixadas no lugar certo) do que erradas. Pois a acusação lançada contra Tirésias não é totalmente falsa - ela apenas encontra-se deslocada no tempo da memória falha e destorcida do herói. As palavras que Sófocles coloca na boca do herói alfinetam a verdade dos acontecimentos ocultados do passado. No verso BL 376, por exemplo, Édipo lamenta que Tirésias teria usado sua arte como ardil, manipulação corrupta a serviço de Creonte, para burlar a (verdadeira) arte do oráculo divino, fomentando as invejas e competições humanas. "Ô riqueza, poder, arte superando a arte na vida repleta de rivalidades!" (BL 376).

Por mais que Édipo esteja errado ao considerar Tirésias como um instrumento nas mãos de Creonte, seu reproche contém, entretanto, uma ponta de verdade. Jocasta revelará que o oráculo anunciando a morte de Laio pela mão do filho nascido de Jocasta (H 733, BL 713) fora burlado por medidas drásticas (a exposição do recém-nascido) que evitaram conseqüências nefastas do oráculo. Ela também erra, mas seu relato indica que o oráculo e o remédio foram ditados pela arte de Tirésias. Neste caso, Édipo está certo e seu pessimismo que denuncia "a arte [como ardil burlando e] superando a arte na vida repleta de rivalidade" (BL 367, H 384) é perfeitamente justificado, Tirésias realmente privou o legítimo herdeiro do trono de seus direitos, sustentando os privilégios monárquicos de um rei e de uma Corte que não souberam preservar Tebas do flagelo da Esfinge

As duas primeiras palavras da exclamação "Ô riqueza, poder" expressam o protesto específico da rivalidade entre gerações, a terceira "arte burlando a arte" refere-se à rivalidade entre saber divino e humano. Como se o herói soubesse a história de seu nascimento, ele dá voz aos protestos do potencial herdeiro do trono, cujos direitos à vida e ao poder foram suprimidos pelo pai - justamente graças aos esforços da arte do vate em superar a arte da profecia divina. Este ardil para proteger o poder e a riqueza de Laio, entretanto, nasceu da cegueira de Tirésias que não soube prever que os Tempos-iam-realizar o estipulado pelo oráculo independentemente dos ardis manipuladores-do vate. Dez versos adiante (BL 385), ele denunciará que o vate nasceu "cego na arte".

Embora diferentemente do que pensa, Édipo acerta com suas suspeitas. Trata-se apenas de aguardar o tempo necessário para que este acerto se encaixe na seqüência de eventos correta. $O$ que há de real neste curioso desvendamento de acertos errados e de erros acertados? A fonte das suspeitas são indícios tênues, quase intangíveis, porém nem por isto irreais. Édipo sente no ar silêncios ameaçadores, lacunas de relatos e reticências. Chegando de Delfos, Creonte procura apla- 
car a impaciência de Édipo anunciando um "feliz desfecho". No mesmo momento, entretanto, ele hesita como se não quisesse expor o oráculo em público. Refere-se ao crime não purificado com termos brandos, como se receasse pronunciar palavras fortes como assassinato, preferindo os eufemismos genéricos que situam a "morte" e o "ocaso" do antigo rei num tempo vago, quase mítico. Considerando a gravidade da omissão das apurações e a ignorância de uma solução no presente, o otimismo inicial parece duplamente leviano, leviana também a desculpa de que a Esfinge teria impedido a purificação. Por mais que Creonte procure ser prestativo e correto, seu modo de falar revela as incongruências e os embaraços-de quem se vê obrigado a tocar nos segredos do passado. O herói - excluído deste passado interpreta os sinais de insegurança como indícios de um complô.

\section{O saber sofrido, inscrito no corpo}

Há uma ameaça surda que paira no ar e ela não é um fantasma inconsistente ou tirânico que surgiria tão somente da imaginação doentio-do herói. As intuições sombrias expressam uma inquietude visceral que, por hora, é difusa estilhaçada em inúmeras percepções apagadas que apenas o tempo reunirá, desvendando o saber sofrido e perfeitamente real do passado. Édipo carrega no seu corpo a cicatriz de ferimentos cuja origem ele desconhece e que atingem sua mente com a paralisia da vergonha. $O$ desconforto da enigmática mutilação física surge à superfície-muito tardiamente, quando Édipo, "surpreendido" pelo mensageiro com a menção da cicatriz dos pés a criança que salvou, grita: "Ah, por que mencionas este velho mal!" (BL 1033). E o velho servidor, feliz de poder identificar-se como o salvador da criança exposta, suscita, enfim, o reconhecimento explícito da vergonha que o rei de Tebas abafar sob as suas conquistas gloriosas: "Deuses, que estranha vergonha paira em torno de meu berço/nascimento!" (BL 1035).

Ao longo da trajetória, Édipo sofreu muitos abalos, mencionou inúmeras angústias e decepções, porém nunca se lembrou do "velho mal" que o afligiu física e moralmente em toda a sua vida. Apenas agora, este mal inscrito no seu corpo se confunde com a outra vergonha: a do filho que desconhece seus pais. Acuado pelo medo, ele confessou a Jocasta a humilhação que roeu sorrateiramente sua honra e a confiança nas palavras paternas até empurrá-lo à fatídica viagem a Delfos. A trajetória do herói está sob a sombra de uma dupla mutilação: a que atinge a integridade de seu corpo e a que atinge sua integração simbólica no corpo social. Somente uma audácia heróica consegue, sempre de novo, superar esta dupla aflição, invertendo o aviltamento num orgulho gerador de proezas. Contra a vergonha de 
ser um bastardo, ele lança o desafio do mérito individual - o princípio democrático ateniense -, que ressoa no consolo dirigido a Jocasta: "Não temas nada. Mesmo que eu seja filho e neto de escravos, isto não te aviltaria!” (BL 1062). Ainda agora, em pleno desfecho funesto, ele resiste ao abatimento da vergonha e se firma no princípio de seu poder.

Este foi conquistado e não se sujeita às velhas convenções monárquicas da "reta" sucessão, na qual o cetro passa de pai para filho ${ }^{20}$.

Neste contexto, cabe lembrar também os detalhes falantes no fatídico encontro de pai e filho na tripla encruzilhada. Laio bate com o [chicote de] duplo ferrão (diplois kentroisi) e é instantaneamente abatido pelo bastão/cetro (skeptrô tupeis). O raio semântico do kentron oscila entre o ferrão que estimula o animal ou excita o desejo até o emblema da soberania, ao passo que o skeptron, bastão que apóia os passos do viajante (ou os pés frágeis de Édipo?) torna-se literalmente o cetro que afirma a soberania do filho sobre o pai.

No orgulho daquele que se gaba de ser filho da "Sorte" (tyché, BL 1080) sente-se a carga reativa de quem lutou incessantemente contra a vergonha e encontrou na "Sorte" sua ilusão eficaz - verdadeira "ficção", artifício confeccionado pela arte humana: poiesis, coisa feita, no lugar da techné. Mas, apesar do orgulho merecido, a vergonha desponta sempre de novo, recordando o estigma aviltante da rejeição que o herói não consegue localizar corretamente no tempo e no espaço.

Ultrapassando a consciência e os conhecimentos racionais, a formulação das suas palavras reúne, no entanto - à maneira dos detetives modernos -, os traços dispersos deste processo esquecido que assim retorna à superfície. Antes de irromperem novamente das trevas do esquecimento, os elementos segmentados das lembranças compartilhadas destorcem a memória falha do herói e o precipitam na procura angustiada dos elos que conectam os signos dispersos num traçado legível.

O saber verdadeiro, a verdade, é, literalmente aquele fundo "não-esquecido" - alethés - que se conserva na memória literal como também na obtusa memória corporal, de forma que o Tempo poderá reintegrá-lo na consciência dos homens. Não somente Édipo, também os outros personagens guardam uma obscura sensibilidade que reage à menção de certos nomes e de palavras nos quais reverberam os ecos de antigos pavores. Esta outra memória - sensível, auditiva e visual registra a verdade (os elementos esquecidos, porém, obscuramente lembrados) na entrelinhas das frases, das intenções e dos conteúdos explícitos.

A lentidão do procedimento que conduzirá Édipo ao reconhecimento difere tanto da lucidez (involuntária e oculta) de suas próprias palavras, como da 
rapidez com que Tirésias profere tão somente o resultado de seu saber ("tu mesmo és a poluição que assola Tebas"). Para compreender humanamente esta palavra obscura, é necessário restabelecer os elos dos acontecimentos, os nexos entre elementos isolados, os agentes invertidos e omitidos. Concentrando sua atenção nos escassos signos disponíveis para a sua consciência, Édipo se propôs a montátos novamente de tal forma que venha a brilhar seu nexo revelador. Com sua capacidade racional de conhecer, procurar e investigar (gnomê e zethesis), Édipo promete "brihar com o deus [Apolo]" ou sucumbir. Ego phanô significa ironicamente: eu elucidarei o crime, brilhando com o deus; no entanto, no caso de Édipo, aparecer no lume da palavra divina significará, tragicamente, que o herói brilhará ao mesmo tempo como aquele que desvendou o criminoso e como aquele que foi revelado como o criminoso. Reunindo os dois sentidos, chegaríamos a um terceiro (que terá também sua validade): a investigação prometida por Édipo não revelará somente a polução-específica sobre a qual Creonte focalizou sua interpretação do oráculo. Édipo impõe um modo humano de investigar; ele reivindica o entendimento racional do encadeamento das causas que levaram a um fato: ele pergunta não somente "quem", mas também "como o culpado causou a peste"? Com esta pergunta e prolonga a perspectiva para os atos violentos envolvendo seu próprio nascimento, a mutilação de seu corpo e sua expulsão.

Por mais que o herói assuma a responsabilidade pelo seu ato, impondo-se a exclusão da comunidade humana, a poética de Sófocles deixa aflorar o encadeamento coletivo da catástrofe. Nas ambigüidades da linguagem e nos excessos de sentido que fogem ao controle, Édipo capta o encobrimento de males "esquecidos". O encadeamento de "velhos e novos males", de um lado, o silêncio do vate, do outro, atraem a atenção do herói sobre a estranha falha de Tirésias. Com efeito, o que significam a estranha inoperância e a aparente indiferença deste sábio diante dos sofrimentos da cidade? A pergunta exasperada "Tu és de pedra?", poderia desdobrar-se na pergunta se a Esfinge não teria algo a ver com os erros de um rei mal aconselhado ou cúmplice/vítima de um mau conselheiro... Com efeito, o espectador pode (e deve) se perguntar qual fora o objetivo de Laio em sua viajem para Delfos? Com certeza, o velho rei procurava um saber que Tirésias não soube ou não quis responder - algo relacionado ou à sucessão ou à Esfinge. A atitude irrequieta do herói, suas inquietudes que culminam na "ira", mostram que suas perguntas surgem de ânsias e desejos vivos - de emoções humanas diametralmente opostas-à solenidade impessoal do vate. Sófocles criou uma-figura profética muito diferente daquela que aparece em Antígona. Na tragédia maisantiga, Tirésias aparece como conselheiro preocupado que implora o rei a seguir suas indicações. Ele fala com calor e insiste 
em nome do bem comum. Em Édipo Rei, ao contrário, o modo de falar do vate oculta sua própria participação nas ações humanas que agitam Tebas, ele revela apenas elos isolados de longas cadeias de acusações.

Em vez de revelar somente o resultado, a investigação do herói fará aparecer a imbricação do destino político da cidade com o destino pessoal - isto é, os elos que ligam os sofrimentos e esperanças de sua própria trajetória com a dos outros. O que mais o irrita e indigna são os sinais de indiferença, a falta de empenho, a frieza dos que permanecem distantes e alheios às dores dos tebanos - a lentidão de Creonte, o silêncio de Tirésias ou do pastor, as reticências de Jocasta e do Coro, são registradas como falhas graves que ameaçam o bem-estar coletivo. Desde os primeiros versos, o herói aparece com sentimentos extremamente fervorosos que vinculam de modo indissociável seu bem pessoal com o da cidade - como se o cultivo deste elo pudesse compensar a fragilidade dos elos que o precipitaram na sua trajetória de exilado. Qualquer gesto que põe em questão o reconhecimento de sua honra ou sua integração na comunidade desencadeia uma suscetibilidade irada. Seus acessos de cólera e impaciência podem parecer, à primeira vista, como deslizes de um caráter egocêntrico, quando, na verdade, correspondem ao esforço hercúleo de construir uma identidade faltante a partir da conquista do bem público para os outros. Se Édipo começa a interessar-se mais pela questão de sua origem do que pelo esclarecimento da morte de Laio, ele somente confirma que todo o seu empenho pela cidade e seus cidadãos tem sua fonte na dor do desenraizamento. Este processo subliminar aparece tão somente nos duplos sentidos involuntários das palavras proferidas. No entanto, é nele que se prepara a possibilidade de redenção do herói, redenção esta que Sófocles formulará na sua última peça, Édipo em Colono..

\section{Notas}

* Profa. Dra. do PPG Filosofia do IFCH/UFRGS.

1 A sigla FHA remete à edição de HÖLDERLIN, 1988; a sigla H indica a numeração da tradução hölderliniana do texto de Sófocles; a sigla BL, a da tradução de Oedipe Roi de Mazon (Paris, Les Belles Lettres, 1985), cuja numeração dos versos segue a das outras edições consagradas.

2 De Musurillo a Vernant e Segal, Édipo ocupa o lugar de um mediador que evidencia as tensões entre o humano, o sub e o sobre-humano, entre o sagrado e o profano, entre as instituiçõe sociais e as forças numinosas, entre o conhecimento racional e o inominável que aguarda nas leis divinas e nos oráulos. A perspectiva aberta pela antropologia 
estrutural pode levar a ver Édipo e Tirésias como os representantes dos pólos que sustentam estas tensões e que se manifestam no conflito entre o saber humano e a sabedoria profética (MUSURILLO, 1957).

3 Hölderlin, ainda mais do que Goethe, o poeta-cientista "pagão", e W. Benjamin salientaram esta atitude "moderna" de Sófocles, que concilia a abstrata distinção do sagrado e do profano. Cf. a tradução dos fragmentos trágicos de W. Benjamin (SZONDI \& BENJAMIN, 1994).

4 Rebecca Bushnell (BUSHNELL, 1988, p. 77) salienta que Édipo age como se estivesse se confrontando com Tirésias num tribunal, ele age como se ambos falassem a mesma linguagem. Nossa perspectiva aprofundara o que há de acerto neste "erro" do herói.

5 Marshall (MARSHALL, 2000, p. 153) salienta as conotações de diagnóstico médico no dialogo acirrado entre Creonte e Édipo. Quando Creonte diz “tu não pensas reto" (ouk orthôs phroneîs, BL 550), a afirmação tem valor de um diagnóstico médico; mas o herói devolve a censura na mesma moeda: ouk eû phronais, BL 552)

6 Sem poder desenvolver o problema, assinalemos somente o elo entre a ação trágica e o fazer revelador da poiésis. Neste contexto, M. Heidegger (HEIDEGGER, 1977, p. 40. 93), e o recente livro de G. Agamben e V. Piazza (AGAMBEN e PIAZZA, 2003, p. 15-37) analisa o conceito heideggeriano da Faktizität, facticidade que se transformará no conceito do Dasein, ser-aí. O ser-aí não é, como em Sartre, o ser-jogado numa contigência dada, mas o ser-áí de Heidegger é e deve vir a ser o seu "aî" (Agamben, 17). Heidegger insiste sobre diferentes modos do ser. Seguindo Santo Agostino, "que escreve, factitia anima est"... "Heidegger quer mostrar que a fê do cristianismo primitivo (diferente da metafísica neoplatônica que pensava o ser como algo sempre disponível [stets Vorhandenes], e, conseqüentemente, a fruitio dei como gozo de uma presença eterna) era uma experiência da vida na sua facticidade e na sua essencial inquietude. Como exemplo desta experiência vital "factica" (faktische Lebenserfahrung), Heidegger analisa uma passagem do capítulo 23 do livro X das Confissões [...] onde Agostinho questiona a relação do homem com a verdade: "Conheci homens que queriam enganar os outros, mas ninguém queria ser enganado... querendo, sem ser enganados, enganar-se a si mesmos, eles amavam a verdade quando esta se desvenda, eles a detestam quando ela os desvenda. E a sanção que a verdade lhes inflige é a seguinte: eles não querem ser desvendados por ela, mas ela os desvenda mesmo assim, permanecendo velada para eles. Assim é feito o coração humano: cego e preguiçoso, indigno e desonesto, ele deseja permanecer escondido, mas ele não quer que algo lhe permanece escondido. Ora, o que lhe ocorre é que ele não permanece oculto à verdade, ao passo que a verdade lhe permanece oculta."

7 Vernant (VERNANT, 1972, v. I, p. 105) assinala o emprego ambíguo dos termos derivados de lethé em Ésquilo, Agamenon, vv. 38-9, onde o vigia, conhecedor das sombrias tramas de Clitemnestra diz: "Para os que sabem, eu falo, para os que não sabem, de propósito, me dissimulo-esqueço (lethomai)". A ironia trágica surge da dissimulação, no discurso dirigido ao interlocutor, de um segundo discurso, contrário ao primeiro, e cujo sentido é perceptível apenas para aqueles que dispõem, em cena ou no público, dos elementos de informação necessários. Sófocles generaliza e estende ao próprio vate este princípio que Ésquilo aplicava somente aos personagens humanos. 
8 Investigaremos ulteriormente o que esta nova forma de saber tem a ver com a dualidade do ser de Édipo que constitui, na pessoa do herói, um enigma (VERNANT, 1972, v. I, p. 105).

9 As oposições do erguido/reto/direito e do desviado/oblíquo/errante são constantes. Cf. v. 38 "erguestes a vida: orthôsai bion sem nada saber ou aprender, mas pelo dom divino (prostheke theou); vv. 46, 50: anorthôson polin; stantes .. orthon, kai pesontes hysteron; v. 51, asphaleia tend'anorthoson polin (com firmeza erga a cidade). Com este pedido contrastam as imagens do movimento labiríntico do herói: v. 66 pollas d'odous elthonta phrontidos planais: meu pensamento passou por muitos caminhos errantes (cf. H714, BL 690-4) expressão que lembra o destino de outra heroína mítica, Antiope, a errante como Io, Europa, possuída por Dionysos (KERÉNYI, 1979, v. II, p. 39). A menção do movimento errante é recorrente em Edipo Rei e em Édipo em Colono: OER v. 727 planema (desvario); 1029 planes (vagabundo); OEC vv. 3, 124 planetes; OEC v. 316 planeô (desviar do caminho reto); OEC v. 304 rumores que se disseminam; OEC v. 315 enganar; OEC v. 1114 caminho errante.

10 É um detalhe interessante o fato que o imaginário mítico usa a imagem do andar claudicante e do pé manco para circunscrever as falhas da sucessão do poder. Karl Kerényi (KERÉNYI, 1979, v. II, p. 72-84) menciona Sete contra Tebas de Ésquilo (v. 750, 802, 842) onde Laio é representado como um rei "claudicante"; quem não consegue tomar uma decisão firme, quem hesita, "manca intelectualmente" e termina gerando filho na embriaguez, loucura (v. 756). Vernant (VERNANT, 1972, p. 49-50) menciona a mesma imagem em Platão, Rép, VII, 535-536: a cholois te kai nothois: aquele que é claudicante intelectualmente (cholois) é um bastardo da alma, mau filósofo; e ainda Plutarco, Agésilas, III, 1-9, fala da realeza claudicante do bastardo (sucessão não é reta do pai para o filho quando a filiação não segue reta da raiz dos Heraclides).

\section{REFERÊNCIAS Bibliográficas}

BUSHNELL, R. Prophesying tragedy. Cornell: Cornell University Press, 1988.

DÉTIENNE, M. Les maîtres de vérité dans la Grèce archaïque. Paris: Maspéro, 1979.

FREUD, S. Gesammelte Werke. Frankfurt am Main: Fisher, 1968.

HEIDEGGER, M. A questão da técnica. Cadernos de tradução. São Paulo, n. 2, p. 40-93, 1977.

HÖLDERLIN, F. Sämtliche Werke. Franfurter Ausgabe, Stromfeld / Roter Stern, 1988.

Sobre a religião. In: Filosofia e literatura. O trágico. Revista de filosofia política. s. III, n. 1, p. 163, 2001.

KERÉNYI, K. Die Mythologie der Griechen. Munich: DTV, 1979.

MAGNIEN. Quelques mots du vocabulaire grec exprimant les opérations ou les états d'âme. Revue des Études Grecques. Paris, XL, p. 117-41. 
MARSHALL, F. Édipo tirano. A tragédia do saber. Porto Alegre: Editora da Universidade, 2000.

MUSURILLO, H. Sunken imagery in Sophocles' Oedipous. AJPH. LXXVIII, 1957.

PIAZZA, V. L'ombre de l'amour. Le concept d'amour chez Heidegger. Paris: Rivages, 2003.

SEGAL, C. Tragedy and civilization. Oklahoma: University of Oklahoma Press, 1999.

SOPHOCLE. Oedipe roi. Texte établi et traduit par P. Mazon. Paris: Les Belles Lettres, 1985.

SZONDI, P.; BENJAMIN, W. Ensaios sobre o trágico. Cadernos de mestrado. Rio de Janeiro, v. II, 1994.

VERNANT, J.-P. Mythe et tragédie. Paris: Maspéro, 1989.

ROSENFIELD, Kathrin Holzermayr. Oedipus' "straying" roads. The sacralization of the positive knowlegde. The profane mistery.

ABSTRACT: This article illuminates the new place that the poetry of Sófocles reserves to knowledge and the figure of the fortune-teller. It highlights the elements that reduce the religious connotations of the intervention of Tiresias in King Oedipus. it shows the techniques with which the poet suggests that the knowledge of the oracles and destiny appear from the threshold of profane "fore-telling" that involves, as a halo, the production of positive knowledge and the practical attitudes of human experience.

KEY WORDS: King Oedipus; mantic wisdom; human knowledge. 